\title{
RISK FACTORS FOR WOUND DEHISCENCE AFTER LAPAROTOMY: A CASE-CONTROL STUDY
}

\author{
Tomas Poškus ${ }^{1}$, Vilius Mačiūnas ${ }^{2}$, Marius Kryžauskas ${ }^{1}$, Saulius Mikalauskas ${ }^{1}$, \\ Donatas Danys', Valdemaras Jotautas ${ }^{1}$, Eligijus Poškus ${ }^{1}$, Kęstutis Strupas ${ }^{1}$ \\ ${ }^{1}$ Vilnius University, Center of Abdominal Surgery, \\ ${ }^{2}$ Vilnius University, Faculty of Medicine
}

Key words: wound dehiscence, eventration, evisceration, risk factors.

\begin{abstract}
Summary
Background. Wound dehiscence is a life-threatening complication with the mortality rate up to $25 \%$. The objective of this study is to identify the risk factors for wound dehiscence after midline laparotomy in adult population.

Methods. The case control study of patients, operated from January 2012 to May 2016, was performed. Patients, who underwent repeated laparotomy for wound dehiscence, were the cases group. Each case was matched by 3 control group patients undergoing similar primary operation. Following characteristics were observed: demographic, past medical and social history, concomitant diseases, intraoperative details, postoperative outcomes and were compared between the groups. Difference was significant, if $\mathrm{p}$ value was less than 0.05 .

Results. 100 patients were included in the study. There were 25 (25\%) patients of the cases group and $75(75 \%)$ patient of the control group. The majority of the patients were males ( $69 \%)$. The mean age was $66.7 \pm 10.8$ years. Three risk factors were identified in the univariate analysis: male gender $(88.0 \%)$, wound infection (56\%) and cardiovascular diseases $(88 \%)$ for wound dehiscence with the mortality rate of $20 \%$. Conclusions. Wound dehiscence is a serious complication with a high mortality rate. The identification of preoperative and early postoperative risk factors may allow preventing and reduce the rate of wound dehiscence.
\end{abstract}

\section{Introduction}

Abdominal wound dehiscence or evisceration is a postoperative wound sutures loss of tightness with the separation of wound edges of the abdominal wall. Moreover, it is lifethreatening complication and the incidence increases within the age up to $10 \%$ among the elderly with the mortality rate up to $25 \%$ [1-4]. The treatment of wound evisceration may be dual: conservative or surgical treatment. The latter is the most common option with urgent repeated midline laparotomy and revision. In order to avoid and reduce the rate of wound dehiscence, the need of risk factors identification is mandatory. Several clinical studies indicated some risk factors which might lead to wound dehiscence during postoperative period $[2,5,6]$.

The aim of this case-control study is to identify the risk factors of wound dehiscence after midline laparotomy in adult population.

\section{Methods}

The case control study of the patients, operated from January 2012 to May 2016, was performed. Patients, who underwent repeated laparotomy for wound dehiscence, were the cases group. Each case was matched by 3 control group patients undergoing similar primary operation.

Following characteristics were observed [8, 9, 19, 21]: demographic (age, gender), past medical and social history (the usage of steroids, the habits of smoking and alcohol usage), concomitant diseases (diabetes, cardiovascular and chronic pulmonary diseases), laboratory tests of hyperglycemia, uremia and coagulopathy, the type of main disease (benign or malignant disease), intraoperative details, postoperative outcomes (wound infection, ascites, peritonitis, sepsis, length of hospital stay) and were compared between the groups. The final result of the treatment was assessed to determine a mortality rate for the patients after abdominal dehiscence closure.

For statistical calculations and result comparison univariate and multivariate analysis methods were used to compare means in groups to determine connection to wound dehiscence. Each observed attribute were evaluated with chi 
square method to determine if variable is significant overall following with comparison to dehiscence using univariate analysis model and finding distribution rate in groups. Case group was compared to control group observing distribution of factors. Dependent variable was set as wound dehiscence occurrence cases and fixed variables were set from the list of observed attributes. Also odds ratio with $95 \%$ confidence interval was compiled to determine reliability interval for means. Multivariate analysis was performed in the same manner calculating distribution rate, odds ratio with $95 \%$ confidence interval. Every comparison of means resulted with unique $p$ value.

Table 1. Type of operation between groups

\begin{tabular}{|l|c|c|c|}
\hline Type of operation & $\begin{array}{c}\text { Cases } \\
\text { group } \\
\mathbf{n}(\%)\end{array}$ & $\begin{array}{c}\text { Control } \\
\text { group } \\
\mathbf{n}(\%)\end{array}$ & p value \\
\hline Colon / rectum & $11(44)$ & $28(37)$ & $>0.05$ \\
\hline Small bowel & $4(16)$ & $21(28)$ & $>0.05$ \\
\hline Pancreas & $5(20)$ & $13(17)$ & $>0.05$ \\
\hline Stomach & $4(16)$ & $6(8)$ & $>0.05$ \\
\hline $\begin{array}{l}\text { Hepatobiliary } \\
\text { system }\end{array}$ & $(0)$ & $5(6)$ & $>0.05$ \\
\hline Other & $1(4)$ & $3(4)$ & $>0.05$ \\
\hline
\end{tabular}

Table 2. Risk factors for wound dehiscence

\begin{tabular}{|l|c|c|c|c|}
\hline Factors & $\begin{array}{c}\text { Case } \\
\text { group } \\
\mathbf{n}(\%)\end{array}$ & $\begin{array}{c}\text { Control } \\
\text { group } \\
\mathbf{n}(\%)\end{array}$ & $\begin{array}{c}\text { Odds ratio } \\
\mathbf{( 9 5} \% \mathbf{C l})\end{array}$ & p value \\
\hline Male & $22(88)$ & $47(63)$ & $4.37(1.2-15.93)$ & 0.017 \\
\hline Female & $3(12)$ & $28(37)$ & $0,23(0.06-0.84)$ & 0.026 \\
\hline $\begin{array}{l}\text { Age (over } \\
60 \text { years) }\end{array}$ & $20(80)$ & $50(67)$ & $\begin{array}{c}1.028(0.989- \\
1.07)\end{array}$ & 0.166 \\
\hline $\begin{array}{l}\text { Smoking } \\
\text { or alcohol } \\
\text { usage }\end{array}$ & $10(40)$ & $23(31)$ & $2.344(0.59-9.36)$ & 0.228 \\
\hline $\begin{array}{l}\text { Nutrition in- } \\
\text { sufficiency } \\
\text { (score 4-5) }\end{array}$ & $4(16)$ & $4(5)$ & $\begin{array}{c}1.644(0.493- \\
5.481)\end{array}$ & 0.418 \\
\hline $\begin{array}{l}\text { Nutrition in- } \\
\text { sufficiency } \\
\text { (score 1-3) }\end{array}$ & $3(12)$ & $19(25)$ & $\begin{array}{c}3.562(0.563- \\
22.54)\end{array}$ & 0.177 \\
\hline $\begin{array}{l}\text { Previous } \\
\text { operations }\end{array}$ & $13(52)$ & $28(37)$ & $\begin{array}{c}1.818(0.729- \\
4.534)\end{array}$ & 0.2 \\
\hline $\begin{array}{l}\text { Diabetes } \\
\text { mellitus }\end{array}$ & $2(8)$ & $10(13)$ & $\begin{array}{c}1.415(0.28- \\
7.158)\end{array}$ & 0.674 \\
\hline $\begin{array}{l}\text { Cardio- } \\
\text { vascular } \\
\text { diseases }\end{array}$ & $22(88)$ & $36(48)$ & $\begin{array}{c}0.126(0.035- \\
0.457)\end{array}$ & 0.002 \\
\hline $\begin{array}{l}\text { Chronic } \\
\text { pulmonary } \\
\text { diseases }\end{array}$ & $7(28)$ & $17(23)$ & $\begin{array}{c}0.754(0.27- \\
2.104)\end{array}$ & 0.589 \\
\hline
\end{tabular}

Difference was significant for final results, if $\mathrm{p}$ value was less than 0.05 .

\section{Results}

Case-control study included 100 patients. There were $25(25 \%)$ of the cases group and $75(75 \%)$ patients of the control group. The mean patient age was $66.7 \pm 10.8$ years, with a range of $20-87$ years. The majority of the patients were males $(69 \%)$. Overall, the $11(44 \%)$ of the patients had full wound dehiscence, whereas $14(56 \%)$ of the patients had partial wound dehiscence in the cases group. The mean time to occur wound dehiscence was $7.0 \pm 2.8$ days, with a range of $1-12$ days after primary operation. All patients of the cases group were revised and resutured during the first 24 hours after noticing a complication. Nevertheless, 1 (4\%) patient had a recurrence of wound infection. The mortality rate was $20 \%$ in cases group. There were no statistically significant percentage difference according to the type of the operation between the cases and control groups. The detailed information is shown in Table 1.

The general risk factors and outcomes with the odds ratio and the $95 \%$ confidence interval are presented in Table 2 and Table 3 . Three risk factors were identified in the univariate analysis: male gender $(88.0 \%)$, wound infection (56\%) and cardiovascular diseases ( $88 \%$ ). The majority of wound dehiscence occurred for patients over 60 years old. Nevertheless, the results were not statistically significant.

\section{Discussion}

This study was performed to investigate the influence of different factors for wound dehiscence development in adult population which may result in higher risk for complication to occur and poor treatment results. Findings showed that the cause of wound dehiscence may be multifactorial. In our study to clarify the risk factors we found that males have a higher risk for dehiscence to occur in comparison to females. Also cardiovascular diseases and postoperative wound infection have major impact to increase risk for wound dehiscence to occur.

As our main strengths for this study we consider summarized list of possible risk factors for wound dehiscence in one medium scale study as we compared each one. Also this study was completely randomized meaning that no group was composed of patients who underwent operation during our given time period without excluding patients who had attributes relevant to study but outcome might have had a negative impact to statistical relevance $[10,11]$. We chose retrospective view for our study excluding prospective study to see if our results may vary in comparison to prospective method $[14,15,19]$. Also we decided to concentrate on 
Table 3. Outcomes, which might lead to wound dehiscence

\begin{tabular}{|l|l|l|l|l|}
\hline $\begin{array}{l}\text { Operation } \\
\text { length (over } \\
150 \text { min) }\end{array}$ & $10(40)$ & $27(36)$ & $0.851(0.342-2.115)$ & 0.729 \\
\hline $\begin{array}{l}\text { Wound in- } \\
\text { fection }\end{array}$ & $14(56)$ & $13(17)$ & $0.165(0.06-0.44)$ & 0.0009 \\
\hline Peritonitis & $13(52)$ & $30(40)$ & $0.586(0.217-1.582)$ & 0.292 \\
\hline Sepsis & $3(12)$ & $12(16)$ & $5.087(0.602-42.987)$ & 0.135 \\
\hline Ascitis & $2(8)$ & $4(5)$ & $0.659(0.101-4.279)$ & 0.662 \\
\hline Mortality rate & $5(20)$ & $11(14)$ & $0.305(0.047-1.991)$ & 0.215 \\
\hline
\end{tabular}

proactive means to evaluate risks and point out possible risk factors eliminating any results that may not be final in particular case This model let us to safely state the risk factor for a case that is finished and may be the basis for early diagnostics of abdominal dehiscence in comparison to reactive model where any actions are made after complication occurs. To ensure minor clinical errors for every case both in research group and control group we analyzed laboratory characteristics examined for routine diagnostics including specific ones for a given case's diagnosis. We observed the most serious conditions for postoperative period that may have major impact in our case-control study. Also we tried to take a closer look at endocrine, respiratory and cardiovascular systems in our search to determine an influence of concomitant diseases [13, 17].

In our study we chose only 100 patients overall in which $25 \%$ were case group patients so as a result we believe that more accurate relevant results may differ if groups were to be expanded of shrunk by significant number of patients. We believe that factors we state as significant and relevant may not change too much but we consider a possibility that some factors who were scarce in groups may become relevant if observed case numbers were to increase meaning that no factor provided in this article was to be interpreted with caution. As we took a closer look to concomitant diseases we had really wide interval of diseases in respiratory and cardiovascular. And evaluation of diseases sorting them by severity or occurrence rate in general population was too complicated for our small number of cases observed to expect a closest accurate result. In this case we chose to look for a different approach and decided to group concomitant diseases according to a system it belongs to meaning that we can't state which condition has the most and which has the least impact for wound dehiscence. We applied this model to respiratory system observing chronic pulmonary diseases and cardiovascular diseases. As follows diabetes was the only endocrine condition for all cases included in this study.

We discovered that male gender has a bigger impact for wound dehiscence in comparison to female gender, yet we think that this significance is multifactorial and mechanism why men have a higher occurrence rate compared to women depends on various other physiologic differences between genders. We would like to imply that men should be considered as patients with higher risk for wound dehiscence moreover if they are sever patients. Cardiovascular disorders as they are connected to poor blood perfusion for tissues lowering their ability to regenerate in physiologic conditions meaning that any cardiovascular disorder that has influence to normal blood flow and protein, carbohydrate, fat acids and etc. transmission is a risk factor concluding in tissue hypoxia and malnutrition. Wound infection may be defined bringing up main phases influenced by bacteria and toxins they excrete. In the inflammatory phase, bacteria and necrotic tissue are phagocytized, and inflammatory factors are released that cause the migration and division of cells involved in the proliferative phase. The proliferative phase or angiogenesis, process with collagen deposition, granulation tissue formation, cell growth, and wound contraction. Toxins and local inflammation overall colonization of bacteria slows regenerative process and most important wound contraction [21].

In comparison to other studies we refer to we found no topical significant difference in results or observed parameters. So in result we think that all the past work done on dehiscence risk factors topic is still relevant and not much has changed in past 10 years considering prognosis, diagnostics, treatment and prevention of abdominal wound dehiscence.

For any future study on risk factors for wound dehiscence in adult population the more in depth look into specific cardiovascular diseases and how different disorder may influence development of complication might provide more aspects as per which one has most impact and which has the least impact in abdominal dehiscence.

\section{Conclusions}

Wound dehiscence is a serious complication with high mortality rate of which preoperative and early postoperative risk factors identification may allow to take measures to prevent or minimize the associated complications. In this case-control study following risk factors were identified to have a negative impact on wound dehiscence development: male gender, wound infection, cardiovascular disorders.

\section{References}

1. Kenig J, Richter P, Żurawska S, Lasek A, Zbierska K. Risk factors for wound dehiscence after laparotomy - clinical control trial. Pol Przegl Chir 2012 Nov;84(11):565-73.

2. Khorgami Z, Shoar S, Laghaie B, Aminian A, Hosseini Araghi N, Soroush A. Prophylactic retention sutures in midline laparo- 
tomy in high-risk patients for wound dehiscence: a randomized controlled trial. J Surg Res 2013 Apr;180(2):238-43.

https://doi.org/10.1016/j.jss.2012.05.012

3. Walters MD, Dombroski RA, Davidson SA, Mandel PC, Gibbs RS. Reclosure of disrupted abdominal incisions. Obstet Gynecol 1990 Oct;76(4):597-602.

4. Seiler CM, Diener MK. Which abdominal incisions predispose for incisional hernias? Chirurg 2010 Mar;81(3):186-91. https://doi.org/10.1007/s00104-009-1816-7

5. Franz MG, Steed DL, Robson MC. Optimizing healing of the acute wound by minimizing complications. Curr Probl Surg 2007 Nov;44(11):691-763.

https://doi.org/10.1067/j.cpsurg.2007.07.001

6. Pieracci FM, Barie PS. Management of severe sepsis of abdominal origin. Scand J Surg 2007;96(3):184-96. https://doi.org/10.1177/145749690709600302

7. de Costa A. Making a virtue of necessity: managing the open abdomen. ANZ J Surg 2006 May;76(5):356-63. https://doi.org/10.1111/j.1445-2197.2006.03638.x

8. Rodríguez-Hermosa JI, Codina-Cazador A, Ruiz B, Roig J, Gironès J, Pujadas M, Pont J, Aldeguer X, Acero D. Risk factors for acute abdominal wall dehiscence after laparotomy in adults. Cir Esp 2005 May;77(5):280-6. Review. Spanish. https://doi.org/10.1016/S0009-739X(05)70854-X

9. Bellón-Caneiro JM. Abdominal wall closure in laparotomy. Cir Esp 2005 Mar;77(3):114-23. https://doi.org/10.1016/S0009-739X(05)70821-6

10. Israelsson L. Choose midline incision for the best access to the abdominal cavity. Lakartidningen 2005 Apr 4-10;102(14):1042$3,1045$.

11. Pérez-Guerra JA, Vázquez-Hernández M, Ramírez-Moreno R, López-García FR. Abdominal re-operations: Prevalence in elective and emergency surgery. Cir Cir 2016 Aug 22. pii: S0009-7411(16)30053-6.

12. Mutafchiyski VM, Popivanov GI, Kjossev KT, Chipeva S. Open abdomen and VAC $\AA$ in severe diffuse peritonitis. J R Army Med Corps 2016 Feb;162(1):30-4.

https://doi.org/10.1136/jramc-2014-000386

13. Goodenough CJ, Ko TC, Kao LS, Nguyen MT, Holihan JL, Alawadi Z, Nguyen DH, Flores JR, Arita NT, Roth JS, Liang MK. Development and validation of a risk stratification score for ventral incisional hernia after abdominal surgery: hernia expectation rates in intra-abdominal surgery. J Am Coll Surg 2015 Apr;220(4):405-13. doi: 10.1016/j.jamcollsurg 2014.12.027.

https://doi.org/10.1016/j.jamcollsurg.2014.12.027

14. Pommerening MJ, Kao LS, Sowards KJ, Wade CE, Holcomb JB, Cotton BA. Primary skin closure after damage control laparotomy. Br J Surg 2015 Jan;102(1):67-75.

https://doi.org/10.1002/bjs.9685

15. Lawson L. All abdominal incisions should be transverse. J Am
Coll Surg 2014 Oct;219(4):846.

https://doi.org/10.1016/j.jamcollsurg.2014.07.001

16. Kenig J, Richter P, Lasek A, Zbierska K, Zurawska S. The efficacy of risk scores for predicting abdominal wound dehiscence: a case-controlled validation study. BMC Surg 2014 Sep $2 ; 14: 65$.

https://doi.org/10.1186/1471-2482-14-65

17. Roy SB, Acharya AN, Sarkar A, Roy SB. A study of the factors related to abdominal wound dehiscense. J Indian Med Assoc 2013 Dec;111(12):847-9.

18. Petersson P, Montgomery A, Petersson U. Wound dehiscence: outcome comparison for sutured and mesh reconstructed patients. Hernia 2014 Oct;18(5):681-9. doi: 10.1007/s10029014-1268-y. Epub 2014 Jun 12.

https://doi.org/10.1007/s10029-014-1268-y

19. Ramneesh G, Sheerin S, Surinder S, Bir S. A prospective study of predictors for post laparotomy abdominal wound dehiscence. J Clin Diagn Res 2014 Jan;8(1):80-3.

20. Meijer EJ, Timmermans L, Jeekel J, Lange JF, Muysoms FE. The principles of abdominal wound closure. Acta Chir Belg 2013 Jul-Aug;113(4):239-44.

https://doi.org/10.1080/00015458.2013.11680920

21. Xing L, Culbertson EJ, Wen Y, Franz MG. Early laparotomy wound failure as the mechanism for incisional hernia formation. J Surg Res 2013 Jun 1;182(1):e35-42. doi: 10.1016/j. jss.2012.09.009. Epub 2012 Sep 23.

https://doi.org/10.1016/j.jss.2012.09.009

\section{RIZIKOS VEIKSNIAI, TURINTYS ITAKOS POOPERACINIŲ ŽAIZDŲ EVENTERACIJAI ATSIRASTI: ATVEJO-KONTROLĖS TYRIMAS T. Poškus, V. Mačiūnas, M. Kryžauskas, S. Mikalauskas, D. Danys, V. Jotautas, E. Poškus, K. Strupas}

Raktažodžiai: eventeracija, evisceracija, skubi chirurgija, pilvo chirurgija, siūlès nesandarumas po laparotomijos, eventeracijos rizikos veiksniai.

Santrauka

Darbo tikslas. Nustatyti ryšį tarp klinikinių veiksnių ir eventeracijų bei ịvardinti rizikos veiksnius pooperacinès žaizdos eventeracijai po laparotomijos atsirasti.

Darbo metodika. Retrospektyvinis atvejo kontrolès tyrimas atliktas 2016 m. Vilniaus universiteto ligoninès Santaros klinikų (VUL SK) Pilvo chirurgijos centre. Tirti 20 - 87 metų pacientai, kuriems 2016 - 2012 metų laikotarpiu atliktos laparotomijos. Ivertintos bendros pacientų klinikinès charakteristikos: lytis, amžius, rūkymo bei alkoholio vartojimo ypatumai, taip pat sergamumas cukriniu diabetu, kardiovaskulinėmis ligomis, lètinèmis kvèpavimo takų ligomis, steroidų vartojimas bei mitybos būklè pagal NRS 2002 skalę. Tirta, ar pagrindinè liga - piktybinis navikas; laboratoriniai rodikliai: uremija, krešejjimo rodikliai, glikemija prieš operaciją ir pooperaciniu laikotarpiu; vertintas pirminis aponeurozès susiuvimo būdas; žaizdos infekcija, anastomozès siūlių nesandarumas po operacijos; ar buvo nustatytas peritonitas, sepsis, asci- 


\section{8}

tas. Matuota hospitalizacijos trukmė RITS ir bendra trukmė. Siekta nustatyti, ịvertinti ryši tarp stebètų klinikinių veiksnių ir žaizdos eventeracijos rizikos. Gauti rezultatai laikyti statistiškai reikšmingais jei $\mathrm{p}<0,05$.

Rezultatai. Tirti 100 pacientai, iš kurių 25 (25\%) žaizdos eventeracijos atvejai ir $75(75 \%)$ atsitiktinai atrinkto paciento kontrolinè grupé, kuriems atlikus laparotomiją, eventeracijos nebuvo; 75 $(75 \%)$ vyrai ir $25(25 \%)$ moteris. Jauniasias pacientas 20 metų (ev.: 39 m.), vyriausias - 87 metų (ev.: 84 m.); amžiaus vidurkis 66,8 $\pm 13,025$ metu (ev.: 69,96 $\pm 13,025$ m.). Vyrų - 22 eventeracijos atvejai (88,0\% visų eventeracijų), moteru -3 atvejai (12,0\% visų eventeraciju), $\mathrm{p}=0,03$. Žaizdos infekcija - 27 pacientams, eventeravo - $14(51,85 \%), \mathrm{p}=0$. Kardiovaskulinès ligos nustatytos 61 pacientui, 22 eventeravę (36,07\%), kurie sudaré 95,45\% eventeravusių, $\mathrm{p}=0$. Eventeravusių pacientų išgyvenamumo prognozė, lyginant su kontroline grupe, prastesnè (20\% : 14,6\%). Hospitalizacijos trukmès vidurkis grupėse tarp RITS ir skyriaus statistiškai reikšmingai nesiskyrè. Bendros hospitalizacijos trukmè grupėse skyrèsi, tačiau statistiškai patikimas rezultatas negautas, $p>0,05$.

Išvados. Pooperacinès žaizdos eventeracijos rizika po laparotomijos statistiškai reikšmingai priklauso nuo paciento lyties, žaizdos infekcijos bei paciento sergamų kardiovaskulinių ligų. Galima teigti, jog šie trys veiksniai didina riziką eventeracijai atsirasti.

Adresas susirašinèti: vilius.maciunas@gmail.com

Gauta 2017-06-05 